\title{
The Impact of Rewards \& Corporate Social Responsibility (CSR) on Employee Motivation
}

\author{
Aroosa khan \\ Department of Management Sciences, The Islamia University of Bahawalpur, Pakistan \\ Email: aroosa54@gmail.com
}

Fatima Latif

Department of Management Sciences, The Islamia University of Bahawalpur, Pakistan

Email: cattymalik60@gmail.com

\begin{abstract}
Wardah Jalal
Department of Management Sciences, The Islamia University of Bahawalpur, Pakistan

Email: wardah.jalal.89@gmail.com
\end{abstract}

\section{Rabia Anjum}

Department of Management Sciences, The Islamia University of Bahawalpur, Pakistan

Email: rabiaanjum83@gmail.com

\author{
Muhammad Rizwan \\ Lecturer, Department of Management Sciences \\ The Islamia University of Bahawalpur, Pakistan \\ E-mail: rizwan.arshad@iub.edu.pk
}

Doi:10.5296/ ijhrs.v4i3.5875 URL: http://dx.doi.org/10.5296/ ijhrs.v4i3.5875

\begin{abstract}
After a long period of research on this topic, motivating employees and retaining them is still a threatening challenge for organizations. The study aims to analyze impact of rewards and corporate social responsibility (CSR) on employee's motivation in Pakistan. This study specifically examines the relationship between intrinsic rewards, extrinsic rewards, internal
\end{abstract}


CSR, external CSR (customer related), external CSR (local communities related), external CSR (business partner related) and employee motivation. It also examines relationship between employee motivation and organizational commitment. Employees of Bahawalpur and Rahim Yar Khan are the sample of this research. Sample size of 150 respondents was used and data collected through self administered questionnaire which was analyzed in SPSS 16 using regression technique. The result depicts that there is significant relationships between extrinsic rewards, external CSR (local communities), external CSR (business partner) and employee motivation and there is also significant relationship between employee motivation and organizational commitment. Management should focus on extrinsic rewards, external CSR (local communities \& business partner related) to motivate employees for organizational commitment.

Keywords: Employees motivation, rewards, corporate social responsibility, organizational commitment, Pakistan

\section{Introduction}

Employee's motivation is the combination of different processes. It has great influence on our behavior in order to achieve some specific goal. The area under discussion is profoundly researched in the perspective of organizational behavior i.e. literature perspectives, theories and models. The quality of human resources mainly affects the progress and prosperity of the organization. A successful organization knows the worth of employees and their motivation. They understand that employees are the most profitable capital of the organization that's why they meet their objectives successfully. Every organization is interested in the ways that can improve the quality of its employees. The efforts towards employee motivation give good results on the basis of excellent human resource management that represent the complete and logical approach which ensure the performance of employees. Human assets are considered as the backbone of the organization. Employee motivation is necessary to get effective and efficient results from employees. There are different motivational factors by which manger tries to motivate individual employees.

The study aims to examine relationship between intrinsic rewards, extrinsic rewards, internal CSR, external CSR, organizational commitment \& employee motivation.

Intrinsic rewards are insubstantial rewards or psychological rewards like appreciation, expectation for better placement and accommodative attitude at par for employees irrespective of their status. Extrinsic rewards are material rewards and these rewards are external to the job or task performed by the employee such as overall compensation like salary/pay, incentives, bonuses, promotions, job security, etc. How an organization try to keep its employees motivated and what method use to assess the performance of employees for job compensation effect the success of an organization?

CSR is comparatively new \& broad management that businesses are beyond the concept of earning rather helpful for betterment of society. CSR should be adopted as an important tool in firm's business for its benefit and improvement (Werther and Chandler, 2006). 
Internal CSR activities are actually in-house activities of the firm whereas external CSR activities refer to throughout external operations linked with customers, concerned communities and active partners having interest in business. The current study on motivation revealed that corporate social responsibility (CSR) activities are key incentives used to motivate employees by companies. Heslin and Ochoa, (2008); Aguilera et al., (2007) found that CSR positively impacts employee turnover, recruitment, satisfaction, retention, loyalty and commitment hence; provide backing to employees and tools to improve motivation.

\section{Literature review:}

\section{Employee motivation}

Numerous attempts found in the literature to define the work motivation (Meyer et al. 2004). That's why there is no general definition of motivation and is not always used appropriately. Latham and Pinder defined employee motivation as:

"a set of active services that derive both inside as well as outside of an individual's being, to began professional attitude and to check out its form, track, strength, and extent" (2005, p. 486).

According to Beer et al, (1984) comprehensive and detailed co operation of employees' motivation is required for organizations to undertake and complete prospect of employees and organization. Motivation is a process in which people are encouraged to move ahead for performing something extraordinary to accomplish their basic needs and get fully satisfied (Butkus \& Green, 1999). Motivation is defined by Baron (1983) as "a set or sequence of actions involved in the push and pulls forces that reinforce the task of the employees towards attainment of definite achievement". Motivation corresponds to "that psychosomatic processes which give rise to stimulation for achievement of desired goals" (Kinicki and Kreitner, 2001). According to Cheng, (1995) the leading challenge for management today is to inspire employees for sake of expert offer and improved services according to customers' prospect. . The main controlling function of Human Resource Managers' is to ensure the satisfactory organizational atmosphere for proper working of employees. . The aim of maximum output through the general manager is to satisfy the employees and to bind up their benefit with their work by providing the inspiration causing acceleration and satisfaction. According to the study of Rutherford (1990) motivation is the effectual driving force in an organization because; motivated employees are constantly inventive in their jobs. Management must appreciate employees and formulate the procedures to accomplish the set target. External motivation keeps a person on job but internal motivation boost up the employees to perform their activities more accurately (Minbaeva, 2008; Rizwan et al., 2013).

Corporate social responsibility (CSR): CSR pinpoints responsibility to firm's stakeholders which depicts comprehensive business superiority of management having responsibilities that range from completion of their duties towards owners and all the firm's stakeholders (Sacconi, 2004).

CSR is a concept with different activities associated with various stakeholders of a company. The internal and external CSR approach is developed by Aguilera et al. (2007), European 
Commission (2001), Brammer et al. (2007), Ligeti and Oravecz (2009) and Smith (2007).

Aguilera et al., (2007); Melynyte and Ruzevicius, (2008); Strautmanis, (2008); Turban and Greening, (1997) found that the factors motivating people to choose that company as the employer are CSR activities in which a particular company is involved. Heslin and Ochoa, (2008) emphasis that majority of indenting employees will try to find such a company which care much about CSR. According to Strautmanis, (2008, p. 348) conclusion of the pragmatic research done in Latvia revealed that "the relations with the labor and society, environmental safety and standards of the production" influenced company's appeal as prospective employer. The job's seekers prefer companies as employer having positive CSR activities. Aguilera et al., (2007); Turban and Greening, (1997); Viswesvaran et al., (2004) states that the signaling theory refers to importance of company's valuation for employment on the basis of social doings prevalent and visible by the applicants.

Internal CSR: Internal CSR activities, in words of Brammer et al., (2007) are associated to all the in-house operational activities of a firm. CSR of this type is more described in the European Commission (2001) Green Paper "Promoting a European framework for corporate social responsibility". Employees are essential in-house stakeholder group and a variety of CSR activities fulfills employees' expectations and requirements. CSR employee-related activities are divided into four categories, named "value classes" which generate the worth for the firm's stakeholders and resultantly, satisfy their variety of hopes (Longo et al., 2005). Employee "value classes" relate to improvement of employees skills, societal justice, health and security at job, and contentment of the workers, and excellence of job.

According to Aguilera et al. (2007) CSR favors employees to fulfill their psychosomatic need of ownership as it promotes the societal interaction both within the organization and among the organizations and socially accountable organizations are typically supposed as good organizations. As a result employees preferably rely upon to behave in a similar approach which is valuable for the firms.

According to Meyer et al., (2004); Locke and Latham, (1990); Mosley et al., (2005); Greenberg and Baron, (2008); Mullins, (2006) the results of the former research verified a positive impact of CSR activities on employee satisfaction, self-worth, group work, trustworthiness, maintenance, psychosomatic need of interacting, employee drive and loyalty and these ideas are linked with employee motivation.

It confirms that such impressions are helpful for association between internal CSR and employee motivation. Therefore, it is hypothesized:

\section{H1. Internal CSR positively correlates with employee motivation.}

External CSR: External CSR would mean donating a fraction of profits towards stakeholder concerns in areas where the company is indirectly concerned in terms of operations. External CSR promotes the mission of positive impacts on society (including economic) and the 
natural atmosphere from business actions and operations. External CSR engage practices related to external stakeholders like customers, local communities and business partners.

External CSR (customer related). European Commission, (2001) states that companies caring social responsibilities are likely to deliver products and services in a well-organized, principled and environmentally friendly style. Customers not only want quality products and services but also quality process of complaint, suggestion and proposals that builds relationships with organizations. Longo et al., (2005) says customers choose the items that are produced keeping insight socially responsible values. Hence, CSR practices have a considerable influence on customers that ultimately effects employee motivation.

External CSR (business partners related). Being socially accountable organization it is compulsory to extent affinity towards its dealing partners. According to Longo et al., company should facilitate trade allies to enhance quality of their output according to terms adopted and agreed on quality control procedures by extending quality goals (2005). In the words of Graafland and van de Van, (2006) adaptation of the labor standards of suppliers and other trade allies in according to lawful procedure and rectification of complaints for them is part of CSR. In other words, companies rely mainly on true business dealings with their suppliers and other business partners that are involved in CSR activities.

External CSR (local communities related). The literature examination depicts that CSR activities toward local communities include humanitarian steps such as funding activities, for sports, societal events. In the words of Aguilera et al., (2007) companies making developmental funding in transportation, water purification plants, education or health are considered as socially responsible. Different persons defined it differently while according to Papasolomou-Doukakis et al., (2005) start community aid projects to inspire their employees to contribute for community relief practices, European Commission, (2001); Ligeti and Oravecz, (2009) states that help brood, ailing or the handicapped or the racial minorities, for example recruit socially excluded people and according to Graafland and van de Van, (2006) offer financial support to social and other non-commercial community projects. All these CSR initiatives lead to formation of additional value not only to the community but to the company as well.

In the words of Aguilera et al., (2007), people are much intending to join the companies whose rules and regulations are reliable with their principled and positive perspective.. Therefore, it is hypothesized:

H2a. External CSR (customers related) positively correlates with employee motivation.

H2b. External CSR (local communities related) positively correlates with employee motivation.

H2c. External CSR (business partners-related partners) positively correlates with employee motivation. 
Rewards: Many researchers work on estimating the linkage between rewards and employee motivation and there exist a huge number of studies found in the literature demonstrating the impact of reward on employee motivation. In order to exploit the concert of the employee's organization must make such policies and measures and put together in such reward system under those policies and measures which increase employee satisfaction and motivation. There should be an effectual reward system to preserve the high performers in the organization and reward should be related to their yield (Carraher et al, 2006).

Intrinsic rewards: Intrinsic rewards are insubstantial rewards or psychological rewards like appreciation, expectation for better placement and accommodative attitude at par for employees irrespective of their status. Intrinsic factors are stronger motivators, and staff motivation requires intrinsic rewards such as satisfaction at doing a good job and a sense of doing something valuable (Frey, 1997).According to study of Asad and Dainty (2005) employees are mostly motivated by intrinsic factors and these factors contribute to their preservation. The link between intrinsic rewards and motivation is well recognized in the literature.

\section{H3: There is a positive relationship of intrinsic rewards with employee motivation.}

External rewards: Extrinsic rewards are material rewards and these rewards exist external to the job or actions performed by the employee such as pay, fringe benefits, job security, promotions, private office space, and the social climate. Mottaz (1985: 366), Mahaney and Lederer (2006: 43) states that external rewards include competitive salaries, pay raises, merit bonuses. According to Prendergast, (1999); Bonner and Sprinkle, (2002) external rewards encourage employees to carry out valuable tasks for the organization. Efficient reward system can be a good motivator but an inefficient reward system can lead to de motivation of the employees. Both intrinsic and extrinsic rewards motivates the employee resulted in higher productivity (Reio and Callahon, 2004)

\section{H4: There is a positive relationship of extrinsic rewards with employee motivation.}

Organizational commitment: According to Pool and Pool Organizational commitment is defined as “. . . One's comparative strength of detection and attachment in a particular organization" (2007, p. 353). Organizational commitment is defined, in words of Mowday et al (1982) as an individual's attitude towards an organization that consists of

(a) A strong confidence in, and acceptance of, the organization's goals and values;

(b) A interest to put forth wide effort on behalf of the organization; and

(c) A strong aspiration to maintain membership in the organization 


\section{Macrothink \\ International Journal of Human Resource Studies

Organizational commitment has three primary components:

(1) A strong belief in and acceptance of the organization's goals and values;

2) A willingness to exert considerable effort on behalf of the organization; and

(3) A strong wish to remain with the organization (Porter et al., 1974).

Luthans, McCaul \& Dodd states that highly committed employees intend to stay within the organization and to work hard toward its goals (1985).

The theorists Basset- Jones and Lloyd, (2005); Chen et al., (2004); Lok and Crawford, (2004); Pool and Pool, (2007) in the area of motivation argue that there is a convincing relationship between motivation and job satisfaction and motivation with employee commitment to the organization. According to Meyer et al., (2004); Locke and Latham, (1990) employee satisfaction, loyalty, retention and commitment are strongly associated to their motivation (Rizwan et al., 2013).

\section{H5: Employee motivation positively correlates with organizational commitment.}

\section{Research methodology:}

\subsection{Sample/Data}

Data is collected through self administered questionnaire from 150 respondents. The current research's population is employees of any type of organization (public/private).

The current study utilizes convenience sampling that is a non-probability sampling technique. Convenience sampling is a sampling technique that obtains and collects the relevant information from the sample or the unit of the study that are easily available (zikmund, 1997).

\subsection{Instrument and Measurement}

The questionnaire contains two sections. Section 1 will obtain different information about personal and demographic variables, like gender, age, income, education and status. Section 2 includes the important latent variables of current study. These variables include organizational commitment, employee motivation, internal CSR (employee related), external CSR (customer related), external CSR (local communities), external CSR (business partner related), intrinsic rewards and extrinsic rewards. Scales of previous studies are used. 


\section{Macrothink}

International Journal of Human Resource Studies

ISSN 2162-3058

2014, Vol. 4, No. 3

Table: scales of the study

\begin{tabular}{|c|c|c|}
\hline No & Variables & Items \\
\hline 1 & $\begin{array}{l}\text { Organizational } \\
\text { Commitment }\end{array}$ & $\begin{array}{l}\text { I would accept almost any type of job assignment in order to keep } \\
\text { working for this organization. } \\
\text { I feel loyalty to this organization. } \\
\text { I am proud to tell others that I am part of this organization. } \\
\text { I talk up this organization to my friends as a great organization to work } \\
\text { for. } \\
\text { It would take very little chance in my present circumstances to cause me } \\
\text { to leave. }\end{array}$ \\
\hline 2 & $\begin{array}{l}\text { Employee } \\
\text { Motivation }\end{array}$ & $\begin{array}{l}\text { I feel a sense of personal satisfaction when I do this job well. } \\
\text { My opinion of myself goes down when I do the job badly. } \\
\text { I take pride in doing my job as well as I can. } \\
\text { I feel unhappy when my work is not up to my usual standard. } \\
\text { I like to look back at a day's work with a sense of a job well done. } \\
\text { I try to think if ways of doing my job effectively. }\end{array}$ \\
\hline 3 & $\begin{array}{l}\text { Internal CSR } \\
\text { (employee } \\
\text { related) }\end{array}$ & $\begin{array}{l}\text { Internal policies prevent discrimination in employees' compensation and } \\
\text { promotion. } \\
\text { A confidential procedure is in place for employees to report any } \\
\text { misconduct at work } \\
\text { (such as stealing or sexual harassment). } \\
\text { Organization has an active programme to promote employee physical } \\
\text { fitness. } \\
\text { Company seeks to comply with all laws regarding hiring and employee } \\
\text { benefits. }\end{array}$ \\
\hline 4 & $\begin{array}{l}\text { External CSR } \\
\text { (customer } \\
\text { related) }\end{array}$ & $\begin{array}{l}\text { Our business has a procedure in place to respond to every customer } \\
\text { complaint. } \\
\text { All our products meet legal standards. } \\
\text { Our salespersons and employees are required to provide full and accurate }\end{array}$ \\
\hline
\end{tabular}




\begin{tabular}{|c|c|c|}
\hline & & information to all customers. \\
\hline 5 & $\begin{array}{l}\text { External CSR } \\
\text { (local } \\
\text { communities } \\
\text { related) }\end{array}$ & $\begin{array}{l}\text { Top managers monitor the potential negative impacts of our activities on } \\
\text { our community. } \\
\text { The managers of this organization try to comply with the law. } \\
\text { Employees feel they are backed up by management if they wish to spend } \\
\text { some time helping a charity. } \\
\text { My organization has a really efficient environmental control and } \\
\text { protection system. }\end{array}$ \\
\hline 6 & $\begin{array}{l}\text { External CSR } \\
\text { (business } \\
\text { partner } \\
\text { related) }\end{array}$ & $\begin{array}{l}\text { The contractual obligations in my organization are always honored. } \\
\text { Fairness toward coworkers and business partners is an integral part of our } \\
\text { employee evaluation process. } \\
\text { Relationships with Small suppliers, Multinational trade unions, } \\
\text { Environmental and other pressure groups are good. } \\
\text { Company has a system to encourage business partners to include social } \\
\text { responsibility criteria in business decisions. }\end{array}$ \\
\hline 7 & $\begin{array}{l}\text { Extrinsic } \\
\text { rewards }\end{array}$ & $\begin{array}{l}\text { My organization is providing fair wage in relation to the effort I devote to } \\
\text { my work, my position, my prior working experience and educational } \\
\text { background. } \\
\text { My organization provides training opportunities to their employees. } \\
\text { My organization has flexibility to establish total/partially the work } \\
\text { schedule. } \\
\text { Work evaluation is based on explicit performance criteria. } \\
\text { Evaluations are fair and constructive. } \\
\text { The organization has set clear criteria for promotions, based on merit and } \\
\text { transparent procedures. }\end{array}$ \\
\hline 8 & $\begin{array}{l}\text { Intrinsic } \\
\text { rewards }\end{array}$ & $\begin{array}{l}\text { The organization allows me to grow as a person, improve } \\
\text { self-confidence, }\end{array}$ \\
\hline
\end{tabular}




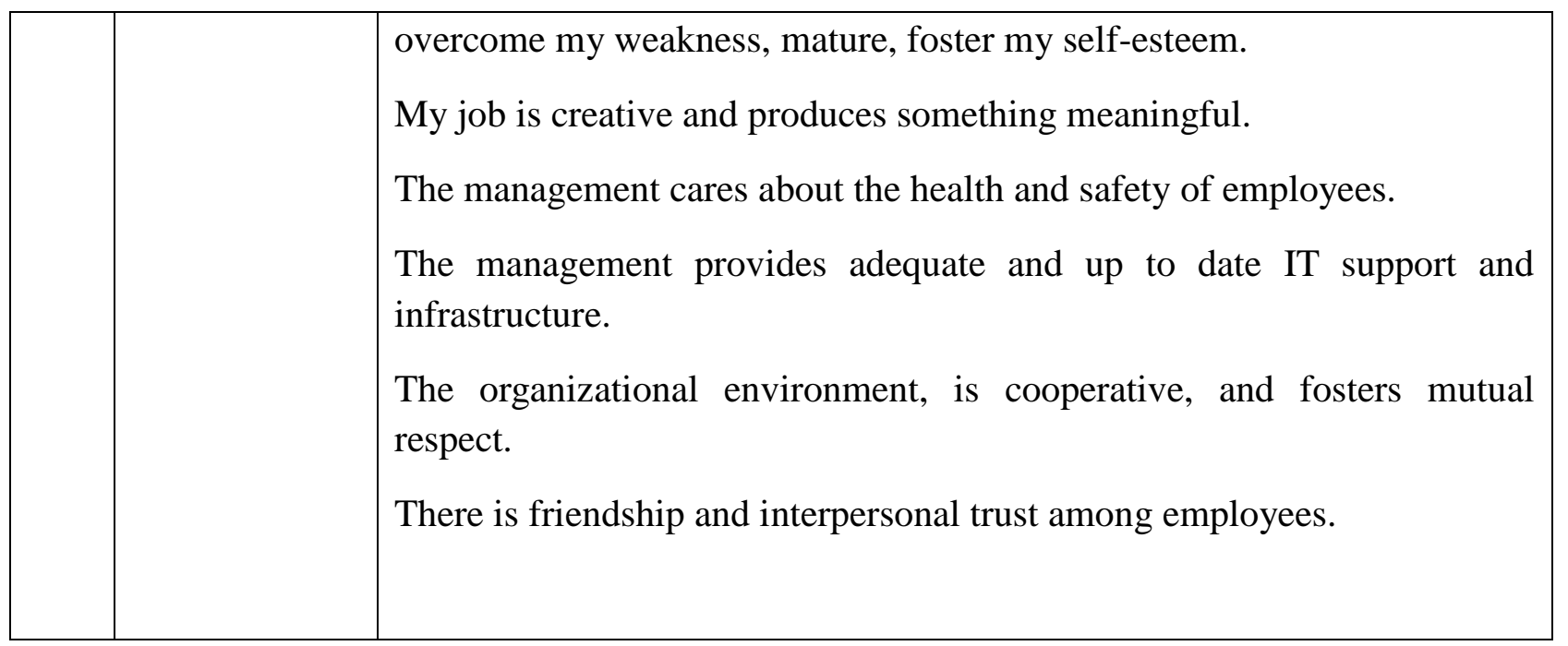

\subsection{Procedure}

The questionnaire was distributed among 150 respondents in Bahawalpur and Rahimyarkhan. Before giving the questionnaire, the purpose of the study and questions were explained to the respondents so they can easily fill the questionnaire with relevant responses. After collecting the completed questionnaires, these questionnaires were entered into SPSS sheet for further analysis.

\subsection{Reliability Analysis}

Cronbach's alpha of all items is more than acceptable and recommended value 0.5 by Nunnally (1970) and by Moss et al. (1998). This means all items were reliable and valid to measure employee motivation.

Table: Reliability of Measurement Instrument

\begin{tabular}{|l|l|l|}
\hline Scales & Items & Cronbach Alpha \\
\hline Organizational commitment & 5 & 0.585 \\
\hline Internal CSR & 4 & 0.722 \\
\hline External CSR(customer) & 3 & 0.736 \\
\hline External CSR(local communities) & 4 & 0.627 \\
\hline External CSR(business partner) & 4 & 0.685 \\
\hline Intrinsic rewards & 6 & 0.733 \\
\hline
\end{tabular}




\begin{tabular}{|l|l|l|}
\hline Extrinsic rewards & 6 & 0.776 \\
\hline Employee motivation & 6 & 0.753 \\
\hline
\end{tabular}

\section{Results and analysis}

\subsection{Profile of the respondents}

Personal and demographic information such as gender, age, income, education level and status are presented in following table.

Table: Profile of the Respondents

\begin{tabular}{|c|c|c|c|}
\hline Variables & Categories & Frequency & Percentage \\
\hline Gender & $\begin{array}{l}\text { Male } \\
\text { Female }\end{array}$ & $\begin{array}{l}98 \\
52\end{array}$ & $\begin{array}{l}65.3 \\
34.7\end{array}$ \\
\hline Age & $\begin{array}{l}\text { 15-20 years } \\
20-25 \text { years } \\
25-30 \text { years } \\
30-35 \text { years } \\
35-40 \text { years } \\
\text { Above } 40 \text { years }\end{array}$ & $\begin{array}{l}21 \\
64 \\
29 \\
22 \\
8 \\
6\end{array}$ & $\begin{array}{l}14 \\
42.7 \\
19.3 \\
14.7 \\
5.3 \\
4\end{array}$ \\
\hline Income & $\begin{array}{l}\text { Below } 15000 \\
15000-25000 \\
25000-35000 \\
35000-45000 \\
45000-55000 \\
\text { Above } 55000\end{array}$ & $\begin{array}{l}31 \\
40 \\
32 \\
23 \\
10 \\
14\end{array}$ & $\begin{array}{l}20.7 \\
26.7 \\
21.3 \\
15.3 \\
6.7 \\
9.3\end{array}$ \\
\hline Education & $\begin{array}{l}\text { Matriculation } \\
\text { Inter } \\
\text { Bachelor } \\
\text { Master }\end{array}$ & $\begin{array}{l}1 \\
44 \\
80\end{array}$ & $\begin{array}{l}0.7 \\
29.3 \\
53.3\end{array}$ \\
\hline
\end{tabular}




\begin{tabular}{|l|l|l|l|}
\hline & $\begin{array}{l}\text { MS/ M. Phill } \\
\text { PhD }\end{array}$ & 25 & 16.7 \\
\hline \multirow{3}{*}{ Company } & Private Ltd. & 92 & 61.3 \\
& Public Ltd. & 58 & 38.7 \\
\hline
\end{tabular}

\subsection{Hypothesis Testing}

\subsubsection{Internal CSR and employee motivation}

The result of the study shows that there is insignificant relationship between internal CSR and employee motivation with $(\beta=0.067)$ and $(\rho>0.05)$. Hence, H1 is rejected.

\subsubsection{External CSR (customer) and employee motivation}

According to result, there is insignificant relationship between external CSR (customer related) and employee motivation with $(\beta=-0.079)$ and $(\rho>0.01)$. The result of study rejected $\mathrm{H} 2 \mathrm{a}$.

\subsubsection{External CSR (local communities) and employee motivation}

The results find that significant relationship lies between external CSR and employee motivation with $(\beta=0.209)$ and $(\rho<0.005)$. That means more than $20 \%$ change in employee motivation was due to external CSR (local communities related). The result supported H2b.

\subsubsection{External CSR (business partner) and employee motivation}

According to the result, there is significant relationship between external (CSR) and employee motivation with $(\beta=0.234)$ and $(\rho<0.005)$. Hence we accept H2c.

\subsubsection{Intrinsic rewards and employee motivation}

According to the result of the study, intrinsic rewards do not correlate with employee motivation. That means there is insignificant relationship between intrinsic rewards and employee motivation with $(\beta=-0.018)$ and $(\rho>0.005)$. we reject the H3.

\subsubsection{Extrinsic rewards and employee motivation}

The result shows that significant relationship exist between extrinsic reward and employee motivation with $(\beta=0.515)$ and $(\rho<0.0001)$. That means extrinsic rewards contribute more than $51 \%$ toward employee motivation. So, H4 accepted.

\subsubsection{Employee motivation and organization commitment}

The result shows that there is a significant relationship between employee motivation and organizational commitment with $(\beta=0.727)$ and $(\rho>0.001)$. So we accept the H5. 


\section{Il Macrothink}

Table: Regression Result

\begin{tabular}{|c|c|c|c|c|c|c|}
\hline Hypothesis & Model Variable & Estimate & $\begin{array}{l}\text { Std. } \\
\text { Error }\end{array}$ & $\begin{array}{l}\text { Critical } \\
\text { region }\end{array}$ & $\rho$ & Result \\
\hline H1 & $\begin{array}{l}\text { Emp } \longleftarrow \\
\text { Int CSR }\end{array}$ & 0.067 & 0.074 & 0.865 & 0.389 & rejected \\
\hline$H 2 a$ & $\begin{array}{l}\text { Emp } \longleftarrow \\
\text { Ex CSR(customer) }\end{array}$ & -0.079 & 0.060 & -1.303 & 0.195 & rejected \\
\hline$H 2 b$ & $\begin{array}{l}\text { Emp } \longleftarrow \\
\text { Ex CSR(local community) }\end{array}$ & 0.209 & 0.076 & 2.903 & 0.004 & supported \\
\hline$H 2 c$ & $\begin{array}{l}\text { Emp } \longleftarrow \\
\text { Ex CSR(business partner) }\end{array}$ & 0.234 & 0.081 & 2.928 & 0.004 & supported \\
\hline$H 3$ & $\begin{array}{l}\text { Emp } \longleftarrow \\
\text { Int rewards }\end{array}$ & -0.018 & 0.098 & -0.192 & 0.848 & rejected \\
\hline H4 & $\begin{array}{l}\text { Emp } \longleftarrow \\
\text { Ex rewards }\end{array}$ & 0.515 & 0.084 & 5.880 & 0.000 & supported \\
\hline H5 & $\begin{array}{ll} & \longleftarrow \\
\text { Org. } & \text { commitment. } \\
\text { Emp Moti } & \end{array}$ & 0.727 & 0.050 & 12.869 & 0.000 & supported \\
\hline
\end{tabular}

\section{Discussion}

The most important resource of an organization to remain competitive in today's competitive business world is human resource. One of the challenges faced by organizations and their management is acquiring the right workforce and then retaining that force. Human resource is the key factor of every organization. Acquiring the right work force is very essential for an organization.

The research results revealed that external CSR (local communities \& business partner) positively influence employee motivation. While insignificant relationship found between internal CSR, external CSR (customer related) and employee motivation. Extrinsic rewards also positively influence employee motivation and positive relationship also exists between employee motivation and organizational commitment. CSR activities to improve companies

image and reputation, the socially responsible behavior of a company management may contribute to the corporate reputation enhancement, bring positive effects related to its stakeholders and gain competitive advantage. But company is not providing CSR (customer 
related).

It is exhumed by result that practical problems can be resolved by giving the importance to the areas of CSR, mainly local communities related and business partner related by executives. Companies could be engaged in CSR activities to improve own image and reputation in the society; bring positive effects related to its stakeholders and attain maximum advantage. CSR activities undertaken by the company that would let the employees to feel like a part of their company and more emotionally engaged into CSR initiatives and feel stronger association with the company. Organization should focus on CSR activities that bring several benefits consistent with organizational goals.

The result reveals that reward system enables to increase employee satisfaction and motivation. It encourages the employees to perform their job with greater responsibility and higher productivity. The external rewards are external rewards which are compensation, benefits and job security. Result oriented reward system leads to motivation of employees having impact on organizational development. The factor discuss above are stronger motivators for achievement of organizational goals and values hence adaptation of efficient reward system is must for organizations. There is a significant and positive relationship between extrinsic rewards and employee motivation but it has been observed that organizations are not offering right intrinsic rewards to their employees in this sector. It is the significant element of the employee motivation. A result doesn't support intrinsic rewards.

No doubt strong ties exist between motivation and job satisfaction and motivation with employee's affinity to organization. Employees attitude toward organization strengthen willingness to achieve organizational goals by highly committed employees by staying within the organization having permanent membership.

\section{Limitations and Future Research}

This study is limited to one country, mainly two cities Bahawalpur and Rahimyar khan. Sample size was small. Data was collected through questionnaires. Data collected through other means like interviews may illustrate the relationships more clearly. In future research, avoiding these limitations may provide additional insight into the under investigation question.

\section{References}

Aguilera, R.V., Rupp, D.E., Williams, C.A. and Ganapathi, J. (2007), "Putting the S back in corporate social responsibility: a multi-level theory of social change in organizations", Academy of Management Review, Vol. 32 No. 3, pp. 836-63.

Amabile, T.M. (1993), "Motivational synergy: toward new conceptualizations of intrinsic and extrinsic motivation in the workplace", Human Resource Management Review, Vol. 3

No. 3, pp. 185-201. 
Armstrong, M. (2006), A Handbook of Human Resource Management Practice, 10th ed., Kogan Page, London.

Asad, S., \& Dainty, A.R.J. (2005). Job motivational factors from disparate occupational groups within the UK construction sector: a comparative analysis. Journal of Construction Research, 6(2), 223-236. http://dx.doi.org/10.1142/ S1609945105000341

Baron, R. A. (1983). Behavior in organizations, p. 123, New York: Allyn \& Bacon, Inc.

Beer, M., Spector, B., Lawrence, P.R., Mills, D.Q., \& Walton, R.E. (1984). Managing human assets. New York: The Free Press

Brammer, S., Millington, A. and Rayton, B. (2007), "The contribution of corporate social responsibility to organizational commitment", International Journal of Human Resource Management, Vol. 18 No. 10, pp. 1701-19.

Carraher, R, Gibson, A. \& Buckley R (2006).Compensation in the Baltic and the USA, Baltic Journal of Management Vol. 1, pp 7-23.

Cheng, H. (1995). Assessing the Importance of Employee Motivation in the Hotel Industry in Taipei, Taiwan. Unpublished master's thesis, University of Wisconsin-Stout, Menomonie, Wisconsin, United States.

Deci, E.L. (1973), "Paying people doesn't always work the way you expect it to", Human Resource Management, Vol. 12 No. 2, pp. 28-32.

Deeprose, D. (1994). How to recognize and reward employees. New York: AMACOM.

Development, Vol. 26 No. 4, pp. 353-69.

Dubin, R. \& Champoux, J. E. (1975). Workers' central life interests and personality characteristics. Journal of Vocational Behavior, 6, pp.165-174.

European Commission (2001), "Promoting a European framework for corporate social responsibility", Green Paper, European Commission, Brussels

Flynn, G. (1998). Is your recognition program understood? Workforce, 77(7), 30-35

Frey. B. (1997). On the Relationship between Intrinsic and Extrinsic Work Motivation. International Journal of Industrial Organization, 15, p 427 - 439.

Graafland, J. and van de Van, B. (2006), "Strategic and moral motivation for corporate social responsibility”, Journal of Corporate Citizenship, Vol. 22, pp. 111-23.

Greenberg, J. and Baron, R.A. (2008), Behavior in Organizations, Prentice-Hall, Upper Saddle River, NJ.

Heslin, P.A. and Ochoa, J.D. (2008), "Understanding and developing strategic corporate social responsibility”, Organizational Dynamics, Vol. 37 No. 2, pp. 125-44. 


\section{Macrothink}

International Journal of Human Resource Studies ISSN 2162-3058 2014, Vol. 4, No. 3

Latham, G.P. and Pinder, C.C. (2005), "Work motivation theory and research at the dawn of the twenty-first century", Annual Review of Psychology, Vol. 56, pp. 485

Ligeti, G. and Oravecz, A ' . (2009), "CSR communication of corporate enterprises in Hungary”, Journal of Business Ethics, Vol. 84 No. 2, pp. 137-49.

Locke, E.A. and Latham, G.P. (1990), "Work motivation and satisfaction: light at the end of tunnel”, Psychological Science, Vol. 1 No. 4, pp. 240-6.

Locke, E.A. and Latham, G.P. (2004), "What should we do about motivation theory? Six recommendations for the twenty first century", Academy of Management Review, Vol. 29 No. 3, pp. 388-403.

Longo, M., Mura, M. and Bonoli, A. (2005), "Corporate social responsibility and corporate performance: the case of Italian SMEs", The International Journal of Effective Board Performance, Vol. 5 No. 4, pp. 28-42.

Luthans, Fred, Harriette S. McCaul, Nancy G. Dodd (1985). Organizational Commitment: A Comparison of American, Japanese, and Korean Employees, The Academy of Management Journal, 28(1), pp.213-219.

Melynyte, O. and Ruzevicius, J. (2008), "Framework of links between corporate social responsibility and human resource management", Forum Ware International, No. 1, pp. 23-34.

Meyer, J. P. \& Allen, N. J. (1991). A three component conceptualization of organizational commitment. Human Resource Management Review, 1(1), pp.61-89.

Meyer, J.P., Becker, T.E. and Vandenberghe, C. (2004), "Employee commitment and motivation: a conceptual analysis an integrative model", Journal of Applied Psychology, Vol. 89 No. 6, pp. 991-1007.

Minbaeva, D. (2008), "HRM practices affecting extrinsic and intrinsic motivation of knowledge receivers and their effect on intra-MNC knowledge transfer", Working Paper No. 12.

Mosley, D.C., Megginson, L.C. and Pietri, P.H. (2005), Supervisory Management: The Art of Inspiring, Empowering, and Developing People, 3rd ed., Thomson, Mason, $\mathrm{OH}$.

Mowday, R.T., Porter, L.W., \& Steers, R.M. (1982). Employees organization linkages. New York: Academic Press

Mullins, L.J. (2006), Essentials of Organisational Behaviour, Financial Times Prentice-Hall, Harlow.

Papasolomou-Doukakis, I., Krambia-Kapardis, M. and Katsioloudes, M. (2005), "Corporate social responsibility: the way forwards? Maybe not!", European Business Review, Vol. 17 No. 3, pp. 263-79. 
Pool, S. and Pool, B. (2007), “A management development model”, Journal of Management

Porter, L.W.; Steers, R.M.; Mowday, R.T.; \& Boulian, P.V. (1974). Organizational commitment, job satisfaction, and turnover among psychiatric technicians. Journal of Applied Psychology, 59, pp.603-609.

Reio, G, T. \& Callahon, J. L. (2004). Affect, Curiosity,and socialization-related Learning; a path analysis of antecedents to job performance, Journal of Business and Psychology, Vol.19, pp3-22.

Rizwan, M., Javeed, K., Nawaz, M. I., Erum, A., Afzal, S., Azam, S. \& Rehman, A. (2013) A descriptive study to explore relationship between HR practices and employee performance in private banks of Pakistan. Journal of Basic and Applied Scientific Research, 3(12), 225-234

Rizwan, M., Shahid, M., Shafiq, H., Tabassum, S., Bari, R. \& Umer, J. (2013) Impact of Psychological Factors on Employee Turnover Intentions, International Journal of Research in Commerce, Economics and Management, 3(3), 63-69

Rutherford, D. G. (1990). Hotel Management and Operations. New York, NY: Van Nostrand Reinhold

Sacconi, L. (2004), “Corporate social responsibility (CSR) as a model of 'extended' corporate governance: an explanation based on the economic theories of social contract, reputation and reciprocal conformism", LUIC, Ethics, Law and Economics Paper No. 142.

Salancik, G, R, (1977). Commitment and the control of organizational behavior and belief. In B. M. Staw BL G. R. Salancik (Eds), New Directions in Organizational Behavior, pp.1-54. Chicago: St, Clair

Smith, A.D. (2007), "Managing the case for the competitive advantage of corporate social responsibility", Business Strategy Series, Vol. 8 No. 3, pp. 186-95.

Strautmanis, J. (2008), “Employees' values orientation in the context of corporate social responsibility”, Baltic Journal of Management, Vol. 3 No. 3, pp. 346-58.

Turban, D.B. and Greening, D.W. (1997), "Corporate social performance and organizational attractiveness to prospective employees", Academy of Management Journal, Vol. 40 No. 3, pp. 658-72.

Viswesvaran, C., Deshpande, S.P. and Milman, C. (2004), "The effect of corporate social responsibility on employee counterproductive behaviour", Cross Cultural Management: An International Journal, Vol. 5 No. 4, pp. 5-12.

Werther, W.B. and Chandler, D. (2006), Strategic Corporate Social Responsibility: Stakeholders in a Global Environment, Sage, London. 